\title{
Citrus pulp and enzyme complex for growing and finishing pigs ${ }^{1}$
}

\section{Polpa cítrica e complexo enzimático para suínos na fase de crescimento e terminação}

\author{
AMORIM, Alessandro Borges ${ }^{2 *}$; THOMAZ, Maria Cristina ${ }^{3}$; RUIZ, Urbano do \\ Santos $^{4}$; MARTINEZ, Juliana Freitas ${ }^{3}$; PASCOAL, Leonardo Augusto Fonseca ${ }^{5}$; \\ DANIEL, Everton ${ }^{3}$; WATANABE, Pedro Henrique ${ }^{6}$; ROSALEN, David Luciano ${ }^{3}$
}

\footnotetext{
${ }^{1}$ Parte da dissertação do primeiro autor.

${ }^{2}$ Univeridade Federal do Mato Grosso, Departamento de Zootecnia, Rondonópolis, Mato Grosso, Brasil.

${ }^{3}$ Universidade Estadual Paulista, Faculdade de Ciências Agrárias e Veterinária, Departamento de Zootecnia, Jaboticabal, São Paulo, Brasil.

${ }^{4}$ Universidade Estadual Paulista, Departamento de Zootecnia, Dracena, São Paulo, Brasil.

${ }^{5}$ Universidade Federal da Paraíba, Departamento de Zootecnia, Areia, Paraíba, Brasil.

${ }^{6}$ Universidade Federal do Ceará, Departamento de Zootecnia, Fortaleza, Ceará, Brasil.

*Endereço para correspondência: alessandrozoo@gmail.com.
}

\section{SUMMARY}

The purpose is to evaluate the effects of levels of citrus pulp (CP), over the aperformance and the carcass characteristics, with or without the addition of an enzyme complex in the feed. Seventy-two pigs were used, at $25.71 \pm 7.51 \mathrm{~kg}$ initial body weight (BW) and $98.81 \pm 10.64 \mathrm{~kg}$ final BW. The diets were formulated for the stages: 1 - 70 to 101 ; 2 - 102 to $130 ; 3$ - 131 to 143 days of age. Because there was no redistribution of the animals in blocks at the beginning of stages 2 and 3, the data were evaluated at the periods: $1-70$ to $101 ; 2-70$ to 130; and $3-70$ to 143 days of age. The inclusion of up to $15 \%$ of $\mathrm{CP}$, with or without the addition of an enzyme complex in the diets, decreased the daily feed intake in Periods 1 and 2, and improved feed:gain in Period 2; however, the animals showed adaptive responses in Period 3. In the absence of the enzyme complex, the carcass yield and the fat/meat ratio decreased linearly as the levels of CP increased. In the presence of the enzyme complex, the fat/meat ratio had a quadratic behavior, and the level of $7.78 \%$ of $\mathrm{CP}$ determined the lowest ratio. The inclusion of up to $15 \%$ of CP with or without the addition of the enzyme complex in diets no differences in performance; therewith, it can be a feed alternative, without effect on the carcass characteristics.

Keywords: alternative ingredient, carcass classification, exogenous enzymes, performance

\section{RESUMO}

Objetivou-se avaliar os efeitos de níveis de polpa cítrica (PC), com ou sem adição de um complexo enzimático nas rações, sobre o desempenho dos suínos e as características de carcaça. Utilizou-se 72 suínos, com $25,71 \pm 7,51$ e 98,81 $\pm 10,64 \mathrm{~kg}$ de pesos inicial e final, respectivamente. As dietas foram formuladas para as fases: 1 - 70 aos 101; 2 102 aos 130; 3 - 131 aos 143 dias de idade. Como não houve redistribuição dos animais nos blocos no início das fases 2 e 3, os dados foram avaliados nos períodos: 1 - 70 aos 101; 2 - 70 aos 130 e 3 70 aos 143 dias de idade. A inclusão de até 15\% de PC, com ou sem a adição do complexo enzimático nas dietas, diminuiu o consumo diário de ração nos Períodos 1 e 2 , e melhorou a conversão alimentar no Período 2, porém, os animais apresentaram respostas adaptativas no Período 3. O rendimento de carcaça e a relação gordura/carne diminuíram linearmente, na medida em que aumentaram os níveis de PC, na ausência do complexo enzimático. Na presença do produto, a relação gordura/carne apresentou comportamento quadrático, e o nível de $7,78 \%$ de PC determinou a menor relação. A inclusão de até $15 \%$ de PC com ou sem a adição do complexo enzimático nas dietas para suínos, não proporciona diferenças no desempenho e pode ser uma alternativa alimentar, sem afetar as características de carcaça.

Palavras-chave: desempenho, enzimas exógenas, ingrediente alternativo, tipificação de carcaça 


\section{INTRODUCTION}

The increase in human population and consequently, the increase in demand for food to satisfy consumption needs, take cereals used in animal feed are increasingly intend for human consumption, thus reducing the availability for animal feed. Thus, it is necessary and important to find alternative ingredients or byproducts to solve or at least mitigate this dependency, as well as improvements in the quality of the meat.

In this sense, Brazil stands out as a major producer of citrus fruit juices, having, thus, a great potential to use in animal feed the by-products generated by its citrus industries. The citrus pulp is the fruit residue after the juice extraction process. The pulp is then submitted to the processes of dehydration and pelleting, which give it good conditions for preservation and storage of the product, what facilitates the feed manufacturing. Normally, such feed is used for ruminants; however, some studies have been made to include this by-product in swine feed (WATANABE et al., 2010).

The usage of by-products in the feed of pigs can be limited due to their chemical compositions, and, in the case of the citrus pulp, its high fiber soluble content or its anti-nutritional factors can impair not only the use of the byproduct by the animal, but also the diet itself.

However, such problems can be minimized or even avoided by the addition of exogenous enzymes to the diets, aiming towards its technical and economic viability. Thus, the use of such additives objectifies the degradation of compounds found in the foods that the animals cannot digest because they do not produce enzymes to degrade them.

Hence, the aim of this research is to verify the effects of different levels of citrus pulp, with or without the addition of an enzyme complex, over the performance of growing and finishing pigs and the carcass characteristics.

\section{MATERIAL E METHODS}

The trial was conducted at the Department of Animal Science of the College of Agricultural and Veterinary Sciences - UNESP, at Jaboticabal Campus, in São Paulo. Seventy-two male, castrated pigs, of Topigs breeding were used, with an initial age of 70 days and $25.71 \pm 7.51 \mathrm{~kg}$ of $\mathrm{BW}$, being monitored until 143 days of age, when they reached $98.81 \pm 10.64 \mathrm{~kg}$ of $\mathrm{BW}$. The animals were housed in individual masonry pens measuring $2.55 \mathrm{~m}^{2}$ each and equipped with semi-automatic feeders and nipple drinkers.

A randomized block design, with a $4 \mathrm{x}$ 2 factorial arrangement, was used, with four levels of citrus pulp, with or without addition of the enzyme complex, with nine replications and one animal constituting the experimental plot. At the beginning of the trial, the animals were weighed and distributed among the following experimental diets, composed mainly of corn and soybean meal and with increasing levels of citrus pulp: CD - control diet; CDE - control diet with the enzyme complex; DCP5 diet with the inclusion of citrus pulp $5 \%$; DCP5E - diet with the inclusion of citrus pulp $5 \%$ and the enzyme complex; DCP10 - diet with the inclusion of citrus pulp 10\%; DCP10E diet with the inclusion of citrus pulp $10 \%$ the enzyme complex; DCP15 - diet with the inclusion of citrus pulp $15 \%$; 
DCP15E - diet with the inclusion of citrus pulp $15 \%$ and the enzyme complex.

The diets (Table 1) were isonutritive and met the nutritional requirements recommended by Rostagno et al. (2005). The diets were formulated for the following stages of the animals: 1 from 70 to 101 days of age; 2 - from 102 to 130 days of age, and 3 - from 131 to 143 days of age. The nutritional values of the citrus pulp, used for the formulation of the diets, were: $23.09 \%$, $18.47 \%, 4.29 \%, 6.86 \%, 1677 \mathrm{kcal} / \mathrm{kg}$, $1.42 \%$, and $0.40 \%$, for neutral detergent fiber (NDF), acid detergent fiber (ADF), starch, crude protein (CP), metabolizable energy (ME), calcium $(\mathrm{Ca})$, and phosphorus available $(\mathrm{P})$, respectively. The enzyme complex was composed of xylanase, $\beta$-glucanase, cellulase, pectinase, and protease, and it was added to the feed at $5 \mathrm{~g} / 100 \mathrm{~kg}$ of feed.

Water and feed were available ad libitum during the whole trial. At the beginning and at the end of each stage, the animals, the provided feed, and the leftovers were weighed to determine Average Daily Gain (ADG), Average Daily Feed Intake (ADFI) and Feed: Gain.

Since there was no redistribution of the animals in the blocks at the beginning of Stages 2 and 3, data were evaluated in the following periods: 1 - from 70 to 101 days of age; 2 - from 70 to 130 days of age; and 3 - from 70 to 143 days of age.

The animals were slaughtered when they reached an average BW of $98.81 \pm$ $10.64 \mathrm{~kg}$. The slaughtering occurred the day after the last weighing, and the animals were submitted to a 12-hour fast for solids prior to boarding transportation to the slaughterhouse. The boarding at the swine division, the transportation, and disembarking at the slaughterhouse lasted approximately two hours. The animals spent 12 hours resting at the slaughterhouse before being slaughtered. Electrical stunning, then bleeding, scalding, dehairing, and evisceration were used in the slaughtering process.

After evisceration, the carcasses were split lengthwise into two halves, and those halves were then weighed. The carcass yield (CY) was obtained by the relation between the weight of the half carcasses and the live weight. Then, the half carcasses were taken to cold storage, at a temperature of $1^{\circ} \mathrm{C}$, and were left there for 24 hours, and then some evaluations were performed.

The following measurements were taken of the left half carcass, according to the Brazilian Method of Carcass Classification (ABCS, 1973): carcass length, which was taken from the cranial edge of the pubic symphysis to the cranial ventral edge of the Atlas; average thickness of fat, resulting from the thicknesses of fat at the heights of the first and last thoracic vertebrae and last lumbar vertebra; ribeye areas (measured at the Longissimus dorsi muscle) and fat areas, both taken at the height of the last rib (region of insertion of the last thoracic vertebra to the first lumbar). Measurements were performed by digital image recording and then AutoCAD $^{\circledR}$ engineering Software was used. The fat/meat ratio was determined by dividing the area of fat by the loin eye area.

There were also taken measurements from the hot carcass weight (HCW) without hooves and head, backfat thickness (BT), and loin depth (LD), obtained between the last and next-tothe-last rib, at six centimeters from the middle dorsal line. Those measurements were taken from the cold left-half carcass with the aid of a caliper rule in order to simulate the reading taken with 
Rev. Bras. Saúde Prod. Anim., Salvador, v.15, n.2, p.369-380 abr./jun., 2014 http://www.rbspa.ufba.br ISSN 15199940

the typification pistol. With the results of HCW, BT and LD obtained, the amount of lean meat (LM) and the percentage of lean meat $(\% \mathrm{LM})$ were calculated according to the following equations proposed by Guidoni (2000):

$$
\begin{aligned}
& \mathrm{LM}=7.38-0.48 * \mathrm{BT}+0.059 * \mathrm{LD}+ \\
& 0.525 * \mathrm{HCW} \\
& \% \mathrm{LM}=65.92-0.685 * 0.094 * \mathrm{LD}- \\
& 0.026 * \mathrm{HCW}
\end{aligned}
$$

\begin{tabular}{|c|c|c|c|c|c|c|c|c|c|c|c|c|}
\hline \multirow{3}{*}{$\begin{array}{l}\text { Ingredients, } \\
\%\end{array}$} & \multicolumn{4}{|c|}{ Stage 1} & \multicolumn{4}{|c|}{ Stage 2} & \multicolumn{4}{|c|}{ Stage 3} \\
\hline & \multicolumn{12}{|c|}{ Levels of Citrus pulp, $\%$} \\
\hline & $0^{1}$ & 5 & 10 & 15 & 0 & 5 & 10 & 15 & 0 & 5 & 10 & 15 \\
\hline Corn & 69.11 & 3.00 & 56.98 & 50.72 & 0.78 & 66.78 & 60.71 & 54.65 & 76.70 & 72.15 & 66.12 & 59.83 \\
\hline $\begin{array}{l}\text { Soybean } \\
\text { meal }\end{array}$ & 26.77 & 7.08 & 27.36 & 27.69 & 23.63 & 23.83 & 24.12 & 24.41 & 19.61 & 19.83 & 20.12 & 20.46 \\
\hline Citrus pulp & 0 & 5 & 10 & 15 & 0 & 5 & 10 & 15 & 0 & 5 & 10 & 15 \\
\hline $\begin{array}{l}\text { Dicalcium } \\
\text { phosphate }\end{array}$ & .24 & 1.24 & 1.25 & 1.26 & 0.99 & 0.99 & 1.00 & 1.00 & 0.82 & 0.82 & 0.83 & 0.83 \\
\hline Lime & DJ & 34 & 0.11 & - & נינת & 0.42 & 0.21 & - & 0.46 & 0.30 & 0.10 & - \\
\hline Soyt & 0.42 & 1.37 & 2.30 & 3.30 & 0.49 & 1.11 & 2.05 & 2.98 & 0.10 & 0.81 & 1.74 & 2.76 \\
\hline $\begin{array}{l}\text { L-Lysine } \\
\mathrm{HCl}\end{array}$ & 0.28 & 0.28 & 0.29 & 0.29 & 0.28 & 0.28 & 0.29 & 0.29 & 0.21 & 0.21 & 0.22 & 0.22 \\
\hline $\begin{array}{l}\text { DL- } \\
\text { Methionine }\end{array}$ & 0.08 & 0.09 & 0.11 & 0.13 & 0.06 & 0.07 & 0.09 & 0.11 & 0.02 & 0.03 & 0.05 & 0.07 \\
\hline L-Threonine & 0.07 & 0.08 & 0.09 & 0.10 & 0.06 & 0.07 & 0.08 & 0.09 & 0.03 & 0.04 & 0.05 & 0.06 \\
\hline $\begin{array}{l}\text { L- } \\
\text { Tryptophan }\end{array}$ & 0.00 & 0.00 & 0.00 & 0.01 & - & 0.00 & 0.00 & 0.01 & - & 0.00 & 0.00 & 0.01 \\
\hline $\begin{array}{l}\text { Min } \\
\text { supp }\end{array}$ & 0.05 & 0.05 & 0.05 & 0.05 & 0.05 & 0.05 & 0.05 & 0.05 & 0.05 & 0.05 & 0.05 & 0.05 \\
\hline $\begin{array}{l}\text { Vitan } \\
\text { Suppl }\end{array}$ & 0.10 & 0.10 & 0.10 & 0.10 & 0.07 & 0.07 & 0.07 & 0.07 & 0.40 & 0.40 & 0.40 & 0.40 \\
\hline Salt & 0.35 & 0.35 & 0.35 & 0.34 & 0.33 & 0.33 & 0.32 & 0.32 & .31 & 0.31 & 0.30 & 0.30 \\
\hline & 1.01 & 1.01 & 1.01 & 1.01 & 2.70 & 1.01 & 1.01 & 1.01 & .29 & 0.04 & 0.01 & 0.01 \\
\hline & 01 & 0.01 & 0.01 & 0.01 & 0.01 & 0.01 & 0.01 & 0.01 & 0.01 & 0.01 & 0.01 & 0.01 \\
\hline Total & 100 & 100 & 100 & 100 & 100 & 100 & 100 & 100 & 100 & 100 & 100 & 100 \\
\hline \multicolumn{13}{|c|}{ Calculated nutritional composition } \\
\hline & & 3230 & 3230 & & & 3230 & & & & & 5250 & 3230 \\
\hline & 18.25 & 18.25 & 18.25 & 18.25 & 17.07 & 17.07 & 17.07 & 17.07 & 15.53 & 15.53 & 15.53 & 15.53 \\
\hline NL & 11.93 & 12.31 & 12.69 & 13.05 & 11.67 & 12.28 & 12.66 & 13.04 & 11.80 & 12.35 & 12.73 & 13.09 \\
\hline $\mathrm{ADF}, \%$ & 4.53 & 5.32 & 6.10 & 6.87 & 4.35 & 5.19 & 5.98 & 6.76 & 4.24 & 5.07 & 5.86 & 6.63 \\
\hline $\mathrm{Ca}, \%$ & 0.63 & 0.63 & 0.63 & 0.68 & 0.60 & 0.60 & 0.60 & 0.59 & 0.48 & 0.48 & 0.48 & 0.53 \\
\hline $\begin{array}{l}\mathrm{P} \text { available, } \\
\%\end{array}$ & 0.33 & 0.33 & 0.33 & 0.33 & 0.28 & 0.28 & 0.28 & 0.28 & 0.25 & 0.25 & 0.25 & 0.25 \\
\hline
\end{tabular}

Table 1. Centesimal and nutritional compositions of the experimental diets used in Stages: 1 - from 70 to 101 days of the pigs' age; 2 - from 102 to 130 days of the pigs' age; and 3 - from 131 to 143 days of the pigs' age

${ }^{1}$ Levels of citrus pulp, with or without enzyme complex; ${ }^{2}$ Assurance levels per $\mathrm{kg}$ of feed: Copper 30mg, Zinc - 160mg, Iodine - 1.900mg, Iron - 100mg, Manganese - 70mg, Selenium - 0.075mg; ${ }^{3}$ Assurance levels per kg of feed: Vit. A - 10000 IU, Vit. D3 - 2500 IU, Vit. E - 18,12mg, Folic acid $0,75 \mathrm{mg}$, Calcium pantothenate $-20 \mathrm{mg}$, Biotin $-6 \mathrm{mg}$, Niacin $-30 \mathrm{mg}$, Pyridoxine $-2.50 \mathrm{mg}$, Riboflavin $0.70 \mathrm{mg}$, Thiamine $-2.50 \mathrm{mg}$, Vit. B12 - 37.50mcg, Vit. K3 - 12.5mg, Colina $-783 \mathrm{mg}$; ${ }^{4}$ The enzyme complex was added to the feed in substitution for the inert. 
Rev. Bras. Saúde Prod. Anim., Salvador, v.15, n.2, p.369-380 abr./jun., 2014 http://www.rbspa.ufba.br ISSN 15199940

The data were submitted to the analysis of variance, using the GLM (General Linear Models) procedure of the SAS statistic program (STATISTICAL ANALYSIS SYSTEM, 2010). The assumptions of normality of the residues were verified by the Cramer-von Mises test.

For the significant interactions $(\mathrm{P}<0.05)$, the levels of citrus pulp were compared by classes of addition of the enzyme complex. When the differences were significant $(\mathrm{P}<0.05)$, the data were submitted to the polynomial regression analysis, having as independent variable the level of citrus pulp added to the diets.

\section{RESULTS AND DISCUSSIONS}

Data referring to ADG, ADFI, and Feed:Gain in the different periods analyzed and the statistics results are shown in Table 2.

Table 2. Values of Average Daily Feed Intake (ADFI), Average Daily Gain (ADG), and Feed:Gain for periods 1, 2, and 3 of pigs receiving feed with different levels of inclusion of citrus pulp (CP), with $(+)$ or without $(-)$ addition of the enzyme complex (EC)

\begin{tabular}{|c|c|c|c|c|c|c|c|c|c|c|c|c|}
\hline \multirow{3}{*}{ Item } & \multicolumn{8}{|c|}{$\mathrm{CP}$ and $\mathrm{EC}$} & \multirow{2}{*}{\multicolumn{3}{|c|}{ Significance $^{3}$}} & \multirow{3}{*}{$\begin{array}{c}\mathrm{CV}^{2} \\
\%\end{array}$} \\
\hline & \multicolumn{2}{|c|}{0} & \multicolumn{2}{|c|}{5} & \multicolumn{2}{|c|}{10} & \multicolumn{2}{|c|}{15} & & & & \\
\hline & - & + & - & + & - & + & - & + & $\mathrm{CP}$ & EC & $\mathrm{CP} * \mathrm{EC}$ & \\
\hline \multicolumn{13}{|l|}{ Period $1^{1}$} \\
\hline $\mathrm{ADFI}^{\mathrm{a}}$ & 1.96 & 2.09 & 2.08 & 2.02 & 1.94 & 1.79 & 1.76 & 1.84 & 0.035 & 1.000 & 0.477 & 15.30 \\
\hline $\mathrm{ADG}$ & 0.83 & 0.88 & 0.89 & 0.84 & 0.85 & 0.74 & 0.71 & 0.80 & 0.224 & 0.940 & 0.220 & 19.94 \\
\hline Feed:Gain & 2.30 & 2.37 & 2.35 & 2.46 & 2.27 & 2.42 & 2.43 & 2.47 & 0.520 & 0.141 & 0.945 & 11.03 \\
\hline \multicolumn{13}{|l|}{ Period 2} \\
\hline $\mathrm{ADFI}^{\mathrm{a}}$ & 2.55 & 2.52 & 2.57 & 2.49 & 2.44 & 2.26 & 2.31 & 2.25 & 0.023 & 0.366 & 0.710 & 12.31 \\
\hline ADG & 0.99 & 0.96 & 1.06 & 1.01 & 0.98 & 0.90 & 0.91 & 0.92 & 0.107 & 0.519 & 0.558 & 15.14 \\
\hline Feed:Gain ${ }^{a}$ & 2.59 & 2.57 & 2.43 & 2.47 & 2.49 & 2.47 & 2.45 & 2.43 & 0.034 & 0.886 & 0.908 & 6.15 \\
\hline \multicolumn{13}{|l|}{ Period 3} \\
\hline ADFI & 2.74 & 2.57 & 2.71 & 2.61 & 2.61 & 2.41 & 2.43 & 2.42 & 0.114 & 0.244 & 0.527 & 12.74 \\
\hline $\mathrm{ADG}$ & 1.01 & 0.97 & 1.01 & 1.00 & 0.98 & 0.93 & 0.93 & 0.95 & 0.449 & 0.648 & 0.586 & 12.80 \\
\hline Feed:Gain & 2.72 & 2.67 & 2.68 & 2.60 & 2.65 & 2.60 & 2.58 & 2.53 & 0.116 & 0.248 & 0.952 & 6.51 \\
\hline
\end{tabular}

${ }^{1}$ Periods: 1 - from 70 to 101 days; 2 - from 70 to 130 days; 3 - from 70 to 143 days of age; ${ }^{2} \mathrm{CV}=$ coefficients of variation; Significant $(\mathrm{P}>0.05)$; ${ }^{\mathrm{a}}$ Linear effect $(\mathrm{P}<0.05)$ for levels of inclusion.

In Period 1, only the ADFI was influenced $(\mathrm{P}=0.0356)$ by the different levels of citrus pulp, and a linear reduction was observed in the feed intake as the levels of citrus pulp increased (Figure 1). The same results was found for ADFI in Period 2
$(\mathrm{P}=0.0239$, Figure 2). There was a linear improvement $(\mathrm{P}=0.0346)$ in the feed conversions due to the results found for ADFI in this last Period and due to the fact that ADG was not affected $(\mathrm{P}>0.05)$ by the different levels of citrus pulp (Figure 3 ). 


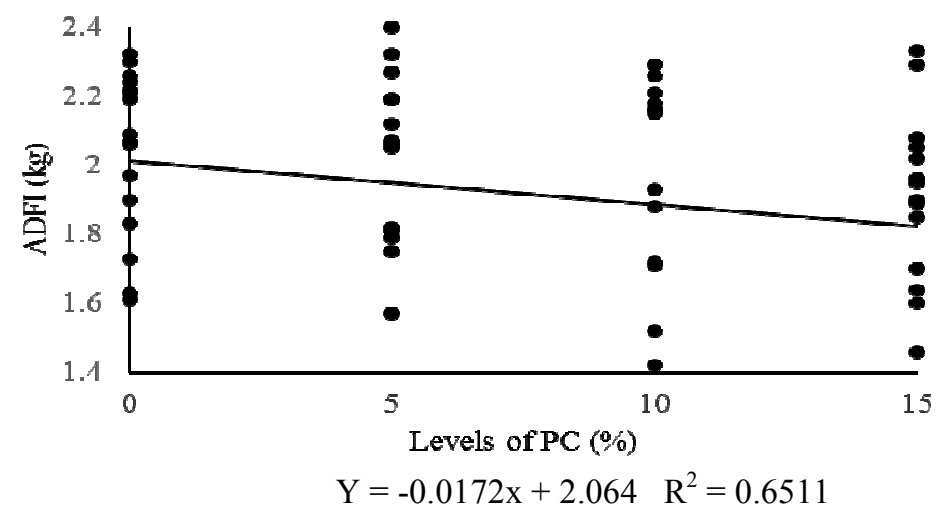

Figure 1. Average Daily Feed Intake - ADFI in Period 1, of growing pigs, receiving different levels of citrus pulp (CP) in their feed

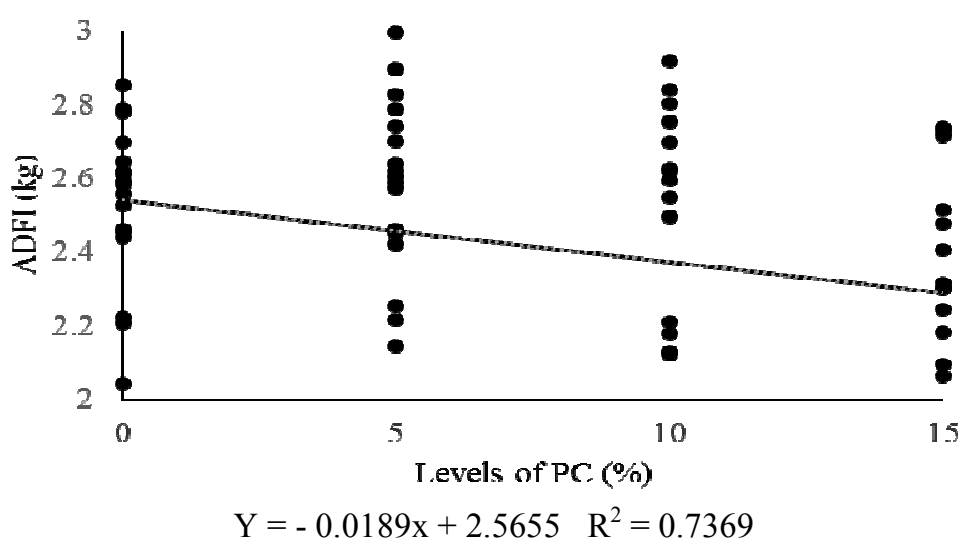

Figure 2. Average Daily Feed Intake - ADFI in Period 2, of growing pigs, receiving different levels of citrus pulp (CP) in their feed

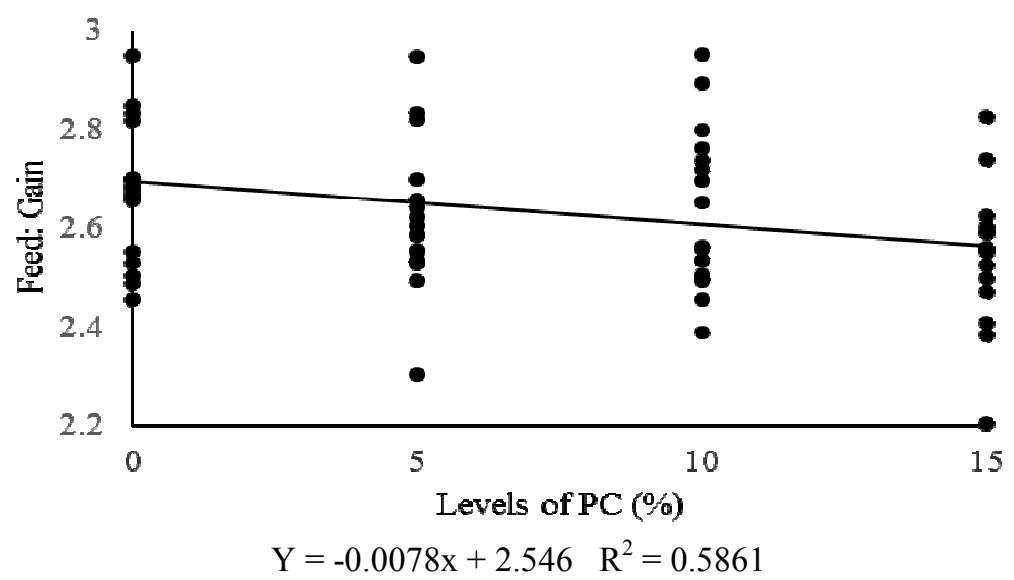

Figure 3. Feed:Gain in Period 2, of growing pigs, receiving different levels of citrus pulp (CP) in their feed 
In Period 3, no differences $(\mathrm{P}>0.05)$ were noticed for the variables studied. The addition or not of the enzyme complex did not affect $(\mathrm{P}>0.05)$ the variables studied, and neither were any significant interactions observed between the levels of citrus pulp and the presence or absence of the complex (Table 2).

In this study, there was a reduction in feed intake regarding the animals fed with increased levels of citrus pulp, which can be justified by the unpalatability of the by-product. Previously, Davis (1947) observed that pigs showed a voluntary reduction in feed intake of diets containing citrus pulp, due to the presence of substances that grant a bitter taste to such ingredient. Younger pigs tend to have greater restrictions to low palatability foods (STERK et al., 2008), which was also verified in this study, when greater restrictions were shown in the first stage.

The type of fiber ingested in the diet can also influence feed intake. Pectin, the main type of fiber present in citrus pulp, has a high capacity of water retention (DROCHNER, 2004) and it can increase the digesta viscosity in the gastrointestinal tract. Such aspects decrease the digesta flow in the intestine, maintaining physical satiety for a longer period and diminishing the animal's stimulus to intake more feed. However, Castro Junior et al. (2005) noticed that ingredients rich in pectin can be put to good use by the pigs, which are animals capable of adapting to new ingredients present in their diets. This was also confirmed in this study, when the total period was observed.

The addition or not of the enzyme complex did not affect $(\mathrm{P}>0.05)$ the variables studied, and no significant interactions were observed between levels of citrus pulp and the presence or not of the referred complex. Omogbenigun et al. (2004) also observed no effects on feed intake when using an enzyme complex in the diets of pigs. Likewise, Emiola et al. (2009) verified that the use of the enzyme complex in the diets was not efficient to improve the performance of growing pigs.

Previous studies show that high levels of cell wall inhibit pig growth, due to the dilution of energy in the diet (Le GOFF et al., 2002). Yet, Souffrant (2001) stated that a high level of fiber in the feed of pigs can stimulate the interaction between this nutrient, the minerals, and the nitrogen, decreasing the use of energy and increasing the digesta passage rate.

When observing the inclusion of enzyme complexes in diets, the results of this current experiment are in agreement with those previously obtained by Pluske \& Lindemann (1998), who researched the effects of an enzyme complex containing amylase, cellulase, pentosanase, protease, and $\alpha$-galactosidase over the performance of growing pigs consuming diets which contained barley and soybean meal or barley and canola, and the researchers did not verify interferences of the enzyme complex over performance. Ruiz et al. (2008) also observed no effects over the performance of the animals when using an enzyme complex containing amylase, cellulase, pentosanase, $\alpha$-galactosidase, and protease added to the diets of growing pigs.

In the present study, the use of the enzyme complex was not capable of improving the animals' performance. It is possible that these results are associated to inadequate levels of the enzymes in the complex used or to the level of inclusion in the diets.

The data referring to the characteristics of the pig carcasses, according to the levels of citrus pulp with or without the addition of the enzyme complex, as well as the results of the statistical analyses, are shown in Table 3. 
Table 3. Average values of the carcass characteristics of pigs and statistical analyses for the different levels of inclusion of citrus pulp (CP), with $(+)$ or without $(-)$ the addition of the enzyme complex (EC)

\begin{tabular}{|c|c|c|c|c|c|c|c|c|c|c|c|c|}
\hline \multirow{3}{*}{ Variables } & \multicolumn{8}{|c|}{$\mathrm{CP}$ and $\mathrm{EC}$} & \multirow{2}{*}{\multicolumn{3}{|c|}{ Significance $^{2}$}} & \multirow{3}{*}{$\mathrm{CV}^{1}(\%)$} \\
\hline & \multicolumn{2}{|l|}{0} & \multicolumn{2}{|c|}{5} & \multicolumn{2}{|c|}{10} & \multicolumn{2}{|c|}{15} & & & & \\
\hline & - & + & - & + & - & + & - & + & $\mathrm{CP}$ & $\mathrm{EC}$ & $\mathrm{CP} * \mathrm{EC}$ & \\
\hline Final weight, $\mathrm{kg}$ & 99.33 & 95.91 & 99.56 & 99.24 & 99.25 & 94.08 & 91.23 & 98.14 & 0.490 & 0.986 & 0.263 & 9.58 \\
\hline Carcass weight, $\mathrm{kg}$ & 77.10 & 74.39 & 77.18 & 77.58 & 76.18 & 72.24 & 68.31 & 74.39 & 0.097 & 0.798 & 0.216 & 9.38 \\
\hline Carcass yield, $\%^{\text {a }}$ & 77.65 & 77.62 & 77.48 & 78.06 & 76.78 & 76.64 & 74.58 & 75.79 & 0.005 & 0.371 & 0.853 & 2.97 \\
\hline Carcass length, cm & 93.06 & 90.28 & 91.78 & 91.33 & 91.13 & 91.61 & 89.44 & 90.00 & 0.793 & 0.635 & 0.273 & 3.93 \\
\hline Average thickness of fat, $\mathrm{mm}$ & 25.20 & 28.11 & 26.37 & 27.88 & 28.08 & 25.23 & 25.38 & 26.00 & 0.359 & 0.395 & 0.532 & 16.60 \\
\hline Loin eye area, $\mathrm{cm}^{2}$ & 35.50 & 38.03 & 35.26 & 37.83 & 34.36 & 33.97 & 33.07 & 35.02 & 0.837 & 0.348 & 0.991 & 21.42 \\
\hline Area of fat, $\mathrm{cm}^{2}$ & 17.32 & 17.87 & 17.09 & 16.02 & 16.98 & 14.42 & 11.66 & 16.26 & 0.281 & 0.820 & 0.138 & 27.25 \\
\hline Fat $/$ meat ratio ${ }^{a, b}$ & 0.48 & 0.47 & 0.49 & 0.42 & 0.46 & 0.38 & 0.35 & 0.47 & 0.195 & 0.596 & 0.015 & 20.55 \\
\hline Hot carcass weight, $\mathrm{kg}$ & 71.41 & 68.90 & 71.48 & 71.85 & 70.56 & 66.91 & 63.27 & 68.90 & 0.097 & 0.797 & 0.216 & 9.56 \\
\hline Backfat thickness, mm & 10.93 & 12.81 & 12.58 & 12.91 & 13.77 & 9.62 & 11.32 & 10.91 & 0.464 & 0.479 & 0.063 & 26.56 \\
\hline Loin depth, mm & 57.03 & 55.92 & 55.80 & 57.70 & 57.37 & 57.90 & 53.63 & 56.66 & 0.572 & 0.289 & 0.604 & 8.34 \\
\hline Lean meat on carcass, $\mathrm{kg}$ & 42.99 & 40.70 & 42.16 & 42.31 & 41.20 & 41.30 & 38.33 & 41.66 & 0.697 & 0.297 & 0.643 & 7.82 \\
\hline Lean meat on carcass, $\%$ & 61.94 & 60.61 & 60.69 & 60.63 & 60.04 & 63.03 & 61.53 & 61.98 & 0.423 & 0.366 & 0.050 & 3.51 \\
\hline
\end{tabular}


The different levels of citrus pulp in the diets did not influence $(\mathrm{P}>0.05)$ the carcass characteristics, except for the carcass yield, which had a linear reduction $(\mathrm{P}=0.0055)$ as the levels of the by-product increased (Figure 4). The presence or not of the enzyme complex in the diets did not influence $(\mathrm{P}>0.05)$ the carcass characteristics, except for the fat $/$ meat ratio $(\mathrm{P}=0.0158)$, which is shown in Figure 5.

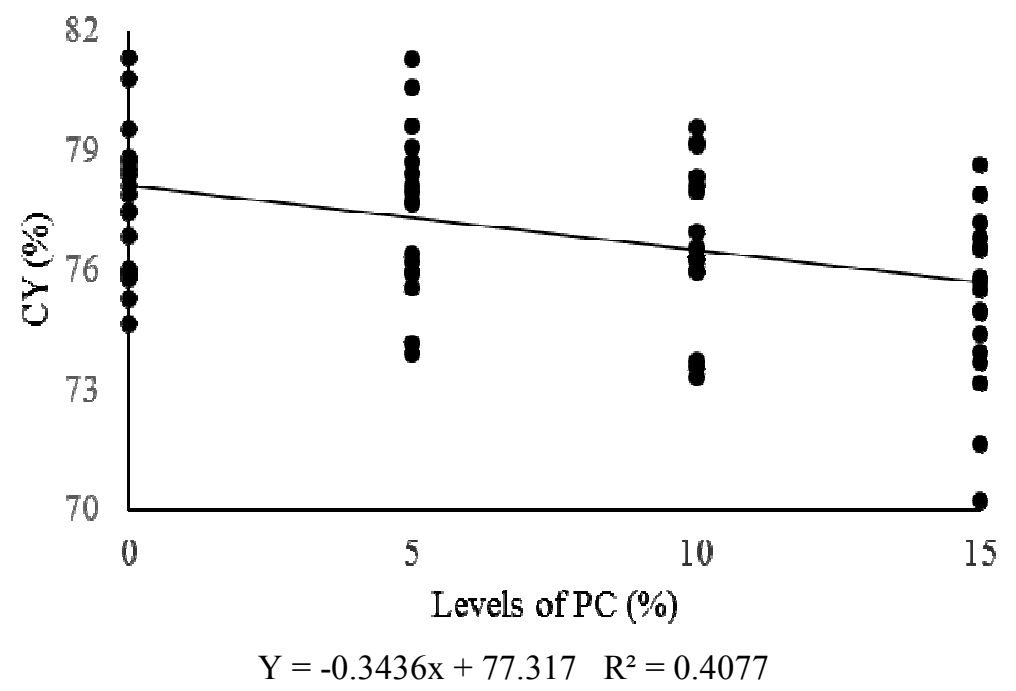

Figure 4. Carcass yield (CY) of pigs receiving different levels of citrus pulp in their feed, without the addition of the enzyme complex

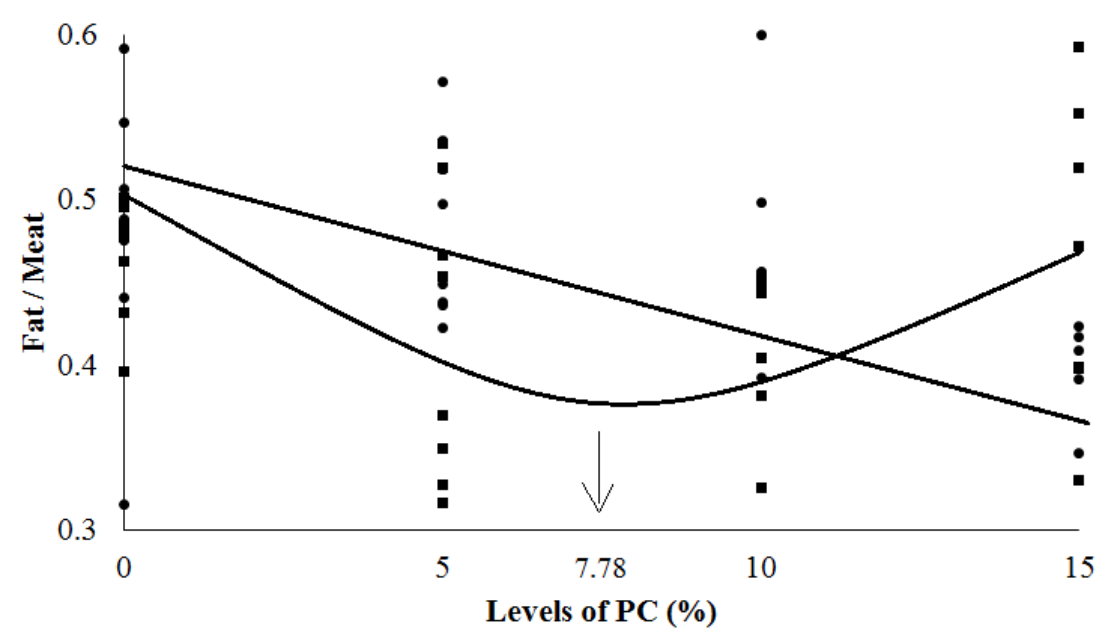

- $\quad$ without enzyme $\mathrm{Y}=-0.0084 \mathrm{x}+0.508 \mathrm{R}^{2}=0.7056$

- $\quad$ with enzyme $\mathrm{Y}=0.0014 \mathrm{x}^{2}-0.0218 \mathrm{x}+0.476 \mathrm{R}^{2}=0.8737$

Figure 5. Fat $/$ meat ratio observed in pigs receiving different levels of citrus pulp in their feed, with or without the addition of the enzyme complex 
When the levels of inclusion of citrus pulp were supplemented with the enzyme complex, a quadratic effect $(\mathrm{P}=0.001)$ was noticed with the minimum point, and the level of $7.78 \%$ of citrus pulp determined the lowest fat $/$ meat ratio.

The carcass yield had a linear reduction $(\mathrm{P}=0.0055)$ as the levels of the byproduct increased. Similar data were previously found by Santomá (1997), who showed that the type of fiber used in the feed of pigs can increase the organs' size in the gastrointestinal tract, decreasing carcass yield. Jorgensen et al. (1996) also observed an increase in the organs' weight in the gastrointestinal tract of pigs when purified pectin and peas were added to the feed.

In relation to the carcass weight, Albuquerque et al. (2011) also verified differences when brewery waste was used in the diets of pigs, and the authors concluded that the use of this byproduct can compose up to $20 \%$ of the diet of finishing pigs, as long as the diet is balanced. However, Barbosa et al. (2003) did not verify differences in carcass length, average fat thickness, loin eye area, fat area, HCW, BT, LD, $\mathrm{LM}$, and \%LM when working with different levels of fiber for finishing pigs. The same was proved by the present study.

Greater quantities of fiber in the diets, without the presence of oil, can decrease efficiency of energy intake by growing and finishing pigs, decreasing the energy available for storage under the form of lipids (FRAGA et al., 2008). In the present study, so that the diets were isoenergetic, it was necessary to add oil, which compensated for the addition of fiber coming from citrus pulp, not decreasing, thus, the fat thickness.
When the levels of inclusion of citrus pulp were supplemented with the enzyme complex, it was observed that the citrus pulp level of $7.78 \%$ determined the lowest fat/meat ratio. Noblet (1996) justified that the fat deposition is directly correlated to the amount of energy consumed by the animal. Moeser et al. (2002) verified that fibrous foods influence negatively the diet energy use. However, the use of enzyme complexes can increase the digestibility of the nutrients, improving the energy use (Hannas \& Pupa, 2003). This can justify the results obtained in the current study for the fat/meat ratio when the enzyme complex was added.

More researches with citrus pulp would be interesting, since decreasing the levels of oil inclusion in the diets and adding another enzyme complex, with other specific enzymes, could have significant responses in the use of byproducts over the performance and carcass characteristics.

The inclusion of up to $15 \%$ of citrus pulp with or without the addition of the enzyme complex in diets for growing and finishing pigs did not result in differences in performance, and it can be a feed alternative, without negative effect on the carcass characteristics. The enzyme complex can be used as a tool for improving the fat/meat ratio.

\section{ACKNOWLEDGEMENTS}

The authors would like to thank the National Council for Scientific and Technological Development $(\mathrm{CNPq}) /$ Brazil for the funding of this work. 
Rev. Bras. Saúde Prod. Anim., Salvador, v.15, n.2, p.369-380 abr./jun., 2014 http://www.rbspa.ufba.br ISSN 15199940

\section{REFERENCES}

\section{ASSOCIAÇÃO BRASILEIRA DE} CRIADORES DE SUIINOS - ABCS.

Método brasileiro de classificação de carcaça. Estrela: ABCS, 1973. 17p. (Publicação Técnica, 2).

ALBUQUERQUE, D.M.N.; LOPES, J.B.; KLEIN JUNIOR, M.H.; MERVAL, R.R.; SILVA, F.E.S.; TEIXEIRA, M.P.F. Resíduo desidratado de cervejaria para suínos em terminação. Arquivo Brasileiros de Medicina Veterinária e Zootecnia, v.63, p.465-472, 2011.

BARBOSA, H.C.A.; VIEIRA, A.S.; ALMEIDA, F.Q.; TEIXEIRA, Z.S.; SOUZA, R.M.; CAMPOS, J.F. Qualidade da carcaça de suínos em terminação alimentados com diferentes restrições alimentar e de energia na dieta. Arquivo Brasileiros de Medicina Veterinária e Zootecnia, v.55, 2003.

CASTRO JÚNIOR, F.G.; CAMARGO, J.C.M.; CASTRO, A.M.M.G.; BUDIÑO, F.E.L. Fibra na alimentação de suínos. Boletim da Indústria Animal, v.62, n.3, p.265-280, 2005.

DAVIS, W.B. Determination of flavonoids in citrus fruit. Analytical Chemistry, v.19, p.476-478, 1947.

DROCHNER, W.; KERLER, A.; ZACHARIAS, B. Pectin in pig nutrition, a comparative review. Journal of Animal Physiology and Animal Nutrition, v.88, p.367-380, 2004.

EMIOLA, I.A.; OPAPEJU, F.O.; SLOMINSKI, B.A.; NYACHOTI, CM. Growth performance and nutrient digestibility in pigs fed wheat distillers dried grains with solubles-based diets supplemented with a multicarbohydrase enzyme. Journal of Animal Science, v.87, p2315-2322, 2009.

FRAGA, A.L.; THOMAZ, M.C.; KRONKA, R.N.; BUDIÑO, F.E.L.; HUAYNATE, R.A.R.; MALHEIROS, E.B. Restrição alimentar qualitativa para suínos com elevado peso de abate.

Revista Brasileira de Zootecnia, v.37, p.869-875, 2008.

GUIDONI, A.L. Melhoria dos processos para tipificação de carcaça suína no Brasil. In: CONFERÊNCIA INTERNACIONAL VIRTUAL SOBRE QUALIDADE DE CARNE SUÍNA, 1., 2000, Concórdia. Anais... Concórdia: EMBRAPA, 2000.

HANNAS, M.I.; PUPA, J.M.R.

Enzimas: uma alternativa viável para enfrentar a crise na suinocultura. Revista PorkWorld, v.2, p.48-51, 2003.

JORGENSEN, H.; ZHAO, X.; EGGUM, B.O. The influence of dietary fibre and environmental temperature on the development of the gastrointestinal tract, digestibility, degree of fermentation in the hind-gut and energy metabolism in pigs. British Journal of Nutrition, v.75, p.365-378, 1996.

Le GOFF, G.; Van MILGEN, J.; NOBLET, J. Influence of dietary fibre on digestive utilization and rate of passage in growing pigs, finishing pigs and adults sows. Journal of Animal Science, v.74, p.503-515, 2002.

MOESER, A.J.; KIM, I.B.; Van HEUGTEN, E.; KEMPEN, TA. The nutritional value of degermed, dehulled corn for pigs and its impact on the gastrointestinal tract and nutrient excretion. Journal of Animal Science, v.80, p2629-2638, 2002. 
NOBLET, J. Net energy for growth in pigs: application to low protein, amino acid supplemented diets. In: THE ONLINE RESOURCE FOR THE PORK INDUSTRY, 1., 1996, Urbana. Proceedings... Urbana: University of Illinois extension, 1996.

OMOGBENIGUN, F.O.; NYACHOTI, C.M.; SLOMINSKI, B.A. Dietary supplementation with multienzyme preparations improves nutrient utilization and growth performance in weaned pigs. Journal of Animal Science, v.82, p.1053-1061, 2004.

PLUSKE, J.R.; LINDEMANN, M.D. Maximizing the response in pig and poultry diets containing vegetable protein by enzyme supplementation. In: ALLTECH ANUAL SYMPOSIUM, 14., 1998, Lexington, Proceedings... Lexington: Nottingham University Press, 1998.

ROSTAGNO, H.S.; ALBINO, L.F.T.; DONZELE, J.L.; GOMES, P.C.; OLIVEIRA, R.F.; LOPES, D.C.; FERREIRA, A.S.; BARRETO, S.L.T

Tabelas Brasileiras para Aves e Suínos: composição de alimentos e exigências nutricionais. 2.ed. Viçosa: UFV, 2005. 186p.

RUIZ, U. dos S.; THOMAZ, M.C.; HANNAS, M.I.; FRAGA, A.L.; WATANABE, P.H.; SILVA, S.Z. da. Complexo enzimático para suínos: digestão, metabolismo, desempenho e impacto ambiental. Revista Brasileira de Zootecnia, v.37, p.458-468, 2008.
SANTOMÁ, G. Máximo de fibra en cerdos en cebo. Factores que influyen sobre el rendimiento de la canal. In: EFECTO DE LA FIBRA SOBRE EL REDIMENTO DE LA CANAL. 13., 1997, Madri. Anales... Madri: Curso de Especializacion Fedna, 1997.

STATISTICAL ANALYSIS SYSTEM. SAS user's guide: statistic. Cary: SAS Institute, 2010.

STERK, A.; SCHLEGEL, P.; MUL, A.J.; UBBINK-BLANKSMA, M.; BRUININX, E.M.A.M. Effects of sweeteners on individual feed intake characteristics and performance in group-housed weanling pigs. Journal of Animal Science, v.86, p.2990-2997, 2008.

SOUFFRANT, W.B. Effect of dietary fibre on ileal digestibility and endogenous nitrogen losses in the pig. Animal Feed Science Technologic, v.90, p.93-102, 2001.

WATANABE, P.H.; THOMAZ, M.C.; RUIZ, U.S. SANTOS, V.M.; MASSON, G.C.I.; FRAGA, L.A.F.; PASCOAL, L.A.F..; ROBLESHUAYNATE, R.A.; SILVA, S.Z. Carcass characteristics and meat quality of heavy swine fed different citrus pulp level. Arquivo Brasileiro de Medicina Veterinária e Zootecnia, v.62, p.921929, 2010.

Data de recebimento: 29/09/2013

Data de aprovação: 29/05/2014 